\title{
Static Analysis of Trailers with Demountable Chassis
}

\author{
Tuğba Gedik ${ }^{(\mathbb{D}}$, Mehmet Vurgun² ${ }^{\mathbb{D}}$, Banu Özkeser ${ }^{3^{*}}$ (D), Erhan Biçer ${ }^{4}$ (D) \\ ${ }^{1}$ Koluman Otomotiv Endüstri A.Ş Ar-Ge Merkezi Mersin, Turkey
}

\begin{abstract}
Today, trailers are the most used vehicles in intercity and international road transport. There are serious difficulties in the production processes and post-production shipments of these vehicles. Trailer chassis are generally produced in welded structures. In this study, the trailer chassis produced in welded structure was transformed into a bolted structure. A nonlinear finite element model was created and static analyzes of the demountable chassis trailer have been made. In these analyzes, stress and deformation data on the chassis part of the trailer were observed. It is concluded that the deformation of the chassis under these loads is at an acceptable level. As a result, it has been shown that welded structures in trailer chassis can be transformed into bolted structures and there is no problem in terms of safety.
\end{abstract}

Keywords: Trailer, Finite Element Method, Demountable Chassis, Traverse

\section{INTRODUCTION}

Road transport constitutes an important part of the logistics industry in the world. Although different vehicles are used, trailers are generally used in road transport. Trailer; It is a road vehicle that is pulled by the truck and connected with a connection device designed according to the characteristics of the load to be transported. It is commonly used for the transport of goods and materials. The most important component of these vehicles carrying the load is the chassis consisting of a steel construction structure. The production process of the trailer chassis, which involves a large amount of welding, poses difficulties for trailer manufacturers in terms of both cost and time. Besides, manufacturers have problems in delivering the trailer chassis produced as a result of the welding process to the customer. In addition, damage to the structure caused by possible accidents in the welded structure increases the costs of maintenance repair and spare parts. Considering the disadvantages of the welded structure, it is thought that a modular chassis can solve these problems.

Bolted connections occupy the most important place in fasteners due to their removable or interchangeable features[1,2]. In terms of mechanical elements, considerable studies have been carried out on the subject in the post2000s period[3-8], as many academic resources have come to the present day[9-14]. Since bolt safety is extremely important, especially when exposed to static and dynamic loads, the work in this area should be adequately examined.
In the study of Jianhua Liu et al., The dynamics of a bolted connection under torsion were examined both experimentally and numerically[15]. In these studies, it has been revealed that there are relative shifts between the clamped parts and between the contact thread.

The stiffness of the connection, which is one of the most important issues in the design of bolted connections, was studied by M. Özkan and K. Dündar[2]. They presented a general solution for element stiffness and pressure propagation angles for bolting the same type of materials and bolting different types of materials and developed an artificial neural network model in this regard. In this study of M. Özkan and K. Dündar, the notch factor required for the strength calculations of bolted connections exposed to variable loadings was taught to the artificial neural network and it was stated that the notch factor value was determined by the user without the need for any table or equation.

On the other hand, in the study on the forces coming to the fasteners in automotive chassis assemblies and the effects of these forces[16], the tightening torque values that form the basis of the joining processes in the chassis joints and the lower and upper limits expressing the tolerances to be addressed in the application of these values were determined within a calculation method. In order to see the accuracy of the method and calculated values, critical connections on a vehicle that was sent to a 30,000 km long-distance test on all road conditions and the route were examined. As a result of the study, it was stated that an approximate calculation was 
put forward in which road test costs were eliminated.

The contact stresses occurring in the bolt-nut connection system were studied by Kubilay Aslantaş et al[17]. A 3D model was developed for the contact stresses occurring in the bolt-nut system exposed to axial load and the study was detailed with the finite element analysis method. It is concluded that the stress values occurring at the thread bottoms of the bolt under the same loading conditions are higher for the nut model and the maximum stresses occur at the thread bottoms where the nut and bolt contact occurs first.

In another study, the behavior of multiple bolt connections under shear and bending loads were determined by Filiz I.H. and Kanber B.[18]. In the study, a symmetrical connection with 6 bolts was considered and subjected to shear and bending loads. In analytical solutions, the elements tightened by the bolts were assumed to be rigid and their effect on bolt deformations was considered to be zero. Two different solutions are made in finite element solutions. In the first, as in analytical solutions, all the elements tightened by the bolts were accepted as rigid and their compatibility with analytical solutions was checked. In the second solution, bolts and connected elements are considered elastic and the differences with the previous solutions have been investigated. Thus, the effect of the rigid assumption in analytical solutions on the results is shown. Infinite element solutions, the preloading effect in connections is also investigated. It has been shown that assuming the elements in analytical solutions to be rigid causes an error of $20 \%$ in the results. Also, it has been reported that the tightening of the bolts shifts the center of rotation upwards.

In a study on the risk of loosening of bolts under vibration[19], the loosening mechanism was modeled with numerical simulation method, an experiment set was prepared within the parameters that were seen to affect the process, and simulations were run. In this study, in which regression analysis and genetic programming were compared, it was reported that the genetic programming method gave more effective results.

Since the transition from welded structure to the bolted structure is in question in demountable chassis studies, a literature study is given on the issues that should be considered in the use of bolts in this section. In the trailer area, there are of course studies such as the use of composite materials and ultra-strong steel to lighten[20]. Besides, life tests are also available, especially in welded structures[21].

Within the scope of the demountable chassis trailer manufacturing, it is essential to transform a welded structure into a bolted structure. On this occasion, the most fundamental content of the study is to reduce the assembly times arising from the welding process, eliminate structural disadvantages arising from the stresses, and most importantly, the transportation of more than one product at a time in terms of logistics. Considering their mounting capabilities, weld- ed and bolted structures have advantages and disadvantages compared to each other. The especially bolted assembly stands out as a fastening technique that does not require qualified personnel, is fast, easier to control and repair, and is not affected by environmental weather conditions during assembly.

In this study, the trailer chassis produced in welded structure was transformed into a bolted structure. A nonlinear finite element model was created and static analyzes of the demountable chassis trailer were made. In these analyzes, stress and deformation data on the chassis part of the trailer were observed. It was concluded that the deformation of the chassis under these loads was at an acceptable level. As a result, it has been revealed that the welded structures on the trailer chassis can be transformed into bolted structures and there are no problems in terms of safety.

\section{MATERIAL AND METHODS}

In Trailer Research \& Development processes, design and design verification capabilities are required. Vehicles are constantly under dynamic and static loads and the transportation time of this load is very long. For this purpose, the structure should be examined in detail using the finite element method in the development processes. Static analysis, dynamic analysis, fatigue analysis, thermal analysis, and modal analysis are at the top of the analysis performed by applying the finite element method. In this study, static and analyzes of the demountable chassis trailer under different loading conditions were run to examine and simulate large deformations, high-stress rates, and complex contact interactions that occur in a short time. The commercial finite element program ANSYS Workbench / Static Structural and Modal analysis programs were used for these analyzes.

\subsection{Numerical Model}

The model used in the study was created by converting the already existing welded trailer chassis into a demountable chassis. The demountable chassis was designed by the Koluman Automotive Industry R\&D department. The detailed model is shown in Figure 1. The analysis model is modeled as symmetrical (half) because the geometry and loading have a symmetrical structure (both physically and geometrically symmetrical). Thus, the solution time was gained. The analysis model was prepared by simplifying it with SpaceClaim Direct Modeler (SCDM) included in the ANSYS software. The detailed model is shown in Figure 2. 


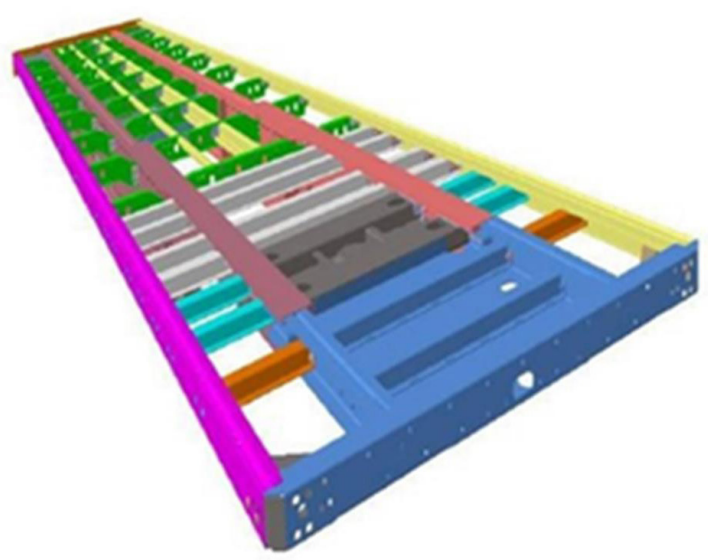

Figure 1. Demountable trailer chassis model

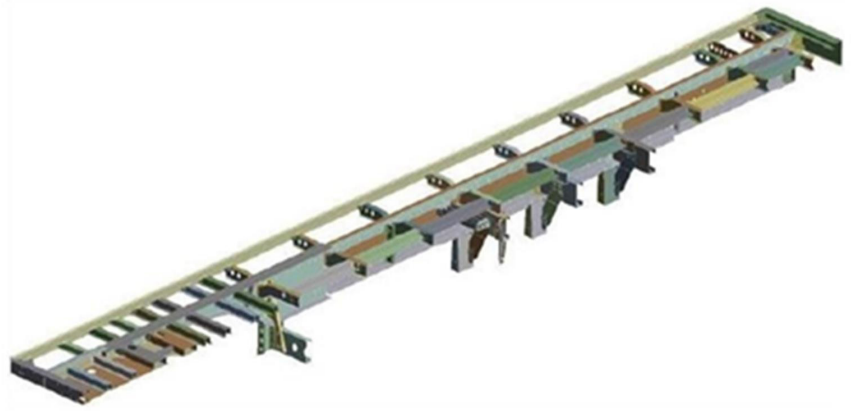

Figure 2. Demountable trailer chassis analysis model (half)

The simplification process is the deletion of parts, sharp corner chamfers and relatively small fillets, fasteners such as bolts and nuts that have no effect on the analysis or are negligible, and the negligible thin sheet metal parts are transformed into 2-dimensional surface elements. This process is done to obtain fast solutions by creating a small number of numerical solution elements. Instead of the deleted bolts in the system, one-dimensional beam elements were placed to represent the bolts. With these elements, shear and axial forces can be read on the analysis result. In this context, various modifications have been made to the holes where the bolts are connected. In order to obtain a more realistic solution, the surfaces of the shell elements are divided to the required size (twice the diameter) to create the cone effect that the bolts create. The same geometry was used in all analyzes.

\subsection{Material Selection}

The raw material generally used in the trailer chassis is S355J2.The number in the name of the structural steel, namely 355 yield strength. It shows the maximum load in MPa that does not end with plastic deformation. S355)2 (St52) steel is a readily weldable low carbon manganese steel with good impact resistance (including in sub-zero temperatures). This material is commonly supplied in untreated or normalized conditions. The machinability of this material is similar to that of mild steel. The chemical composition and mechanical features of S355)2 (St-52) material are shown in Tables 1 and 2.
Table 1. S355J2 (St-52) Mechanical Features S355)2 (St-52) Mechanical Features

\begin{tabular}{|c|c|c|c|c|}
\hline \multicolumn{5}{|c|}{ S355/2 (St-52) } \\
\hline Material & $\begin{array}{c}\text { Density } \\
{\left[\mathrm{kg} / \mathrm{m}^{3}\right]}\end{array}$ & $\begin{array}{c}\text { Poisson } \\
\text { Ratio [-] }\end{array}$ & $\begin{array}{c}\text { Elastic Modulus } \\
{[\mathrm{GPa}]}\end{array}$ & $\begin{array}{c}\text { Yield Strength } \\
{[\mathrm{MPa}]}\end{array}$ \\
\hline St-52 / S355 & 7850 & 0.3 & 210 & 355 \\
\hline
\end{tabular}

Table 2. S355J2 (St-52) Mechanical Features

\begin{tabular}{|c|c|c|c|c|c|c|c|}
\hline \multicolumn{7}{|c|}{ S355)2 (St-52) Chemical Composition } \\
\hline $\mathrm{C}$ & $\mathrm{Si}$ & $\mathrm{Mn}$ & $\mathrm{P}$ & $\mathrm{S}$ & $\mathrm{Ni}$ & $\mathrm{Cr}$ & $\mathrm{Fe}$ \\
\hline $\begin{array}{c}0.2 \% \\
(\max )\end{array}$ & $\begin{array}{c}0.55 \% \\
(\max )\end{array}$ & $1.60 \%$ & $0.02 \%$ & $\begin{array}{c}0.025 \\
\%\end{array}$ & $\begin{array}{c}0.3 \% \\
(\max )\end{array}$ & $\begin{array}{c}0.3 \% \\
(\max )\end{array}$ & $\begin{array}{c}\text { remain- } \\
\text { der }\end{array}$ \\
\hline
\end{tabular}

\subsection{Meshing Model}

In order to obtain accurate results in analysis, it is necessary to choose the appropriate mesh method. A suitable mesh structure was created in the simplified and ready-for-analysis model. A total of 688,266 nodes and 667,636 items were used in the created solution network. This network structure is shown in Figure 3.

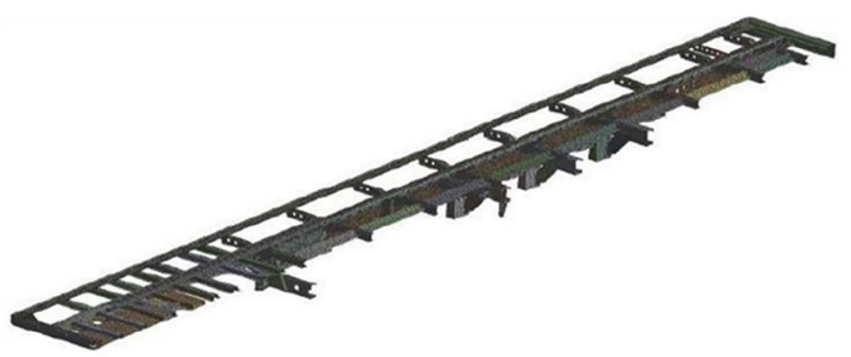

Figure 3. The mesh structure of the analyses model

\section{RESULTS AND DISCUSSION}

Since the part exposed to the greatest load on the demountable chassis is the I-profile, the analysis was applied to this profile. The analysis results are given in detail below. In the analysis, $15000 \mathrm{~N}$ loads were applied to both sides of the connections. In addition to these loads, standard gravity is also included in the analysis. These boundary conditions are shown in Figures 1 and 2.

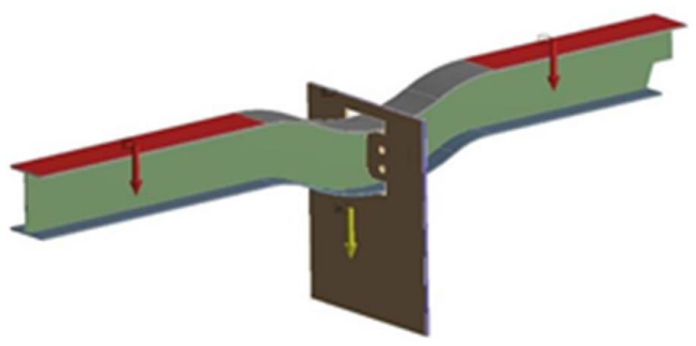

Figure 4. The welding boundary conditions

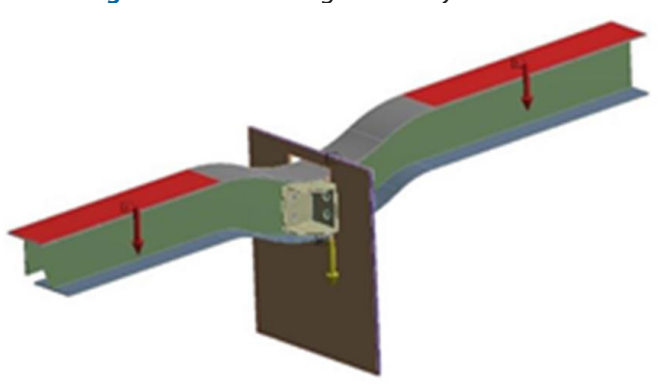

Figure 5 . The assembly boundary conditions 
As a result of the loads applied in the analysis, the stress in the welded structure I-profile traverse is $404 \mathrm{MPa}$ and the deformation is $20 \mathrm{~mm}$. The stress resulting from the loads applied on the demountable I-profile traverse is $420 \mathrm{MPa}$ and the deformation is $10 \mathrm{~mm}$. According to the results of this analysis, while the stress at the connection points increased by $3.96 \%$, the amount of deformation decreased by $50 \%$. Stresses and deformations of structures are shown in Figures 6, 7, 8, and 9 .

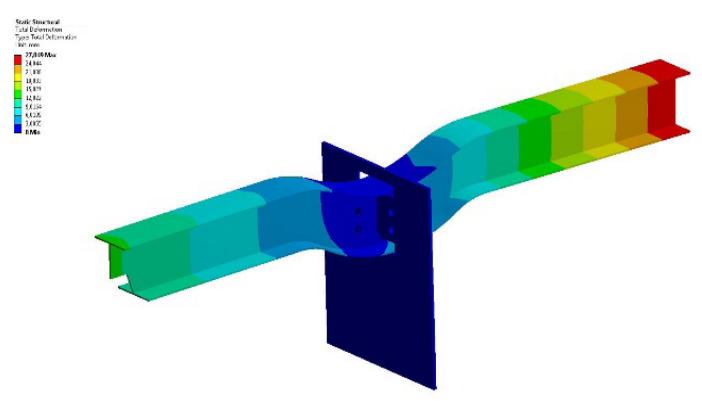

Figure 4. The welding boundary conditions

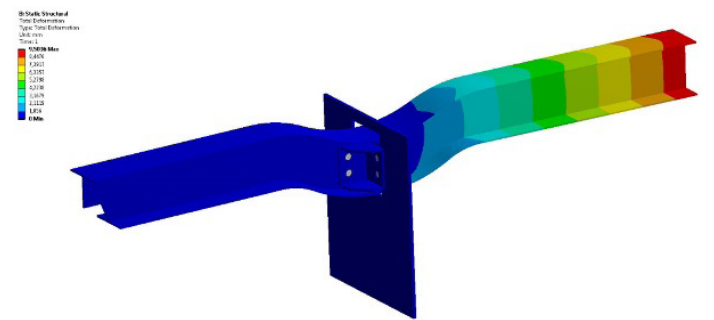

Figure 7. The assembly deformation

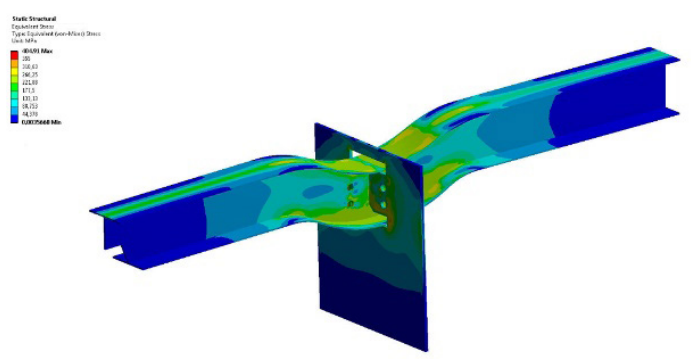

Figure 8. The welding stress

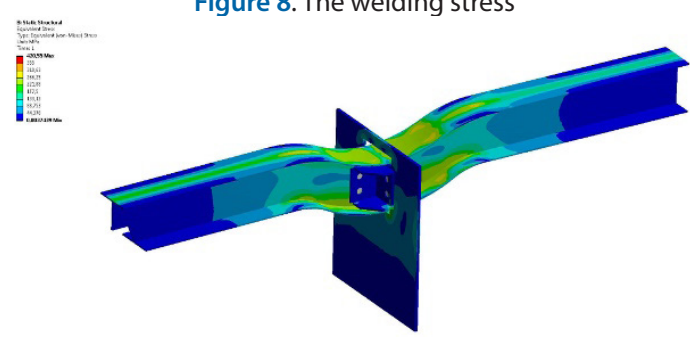

Figure 9. The assembly stress

In addition to the comparisons of the I-profile traverses given above, the U-profile traverse analyzes, which are the main form, were also performed. In the following table, the stress and deformation comparisons of welded structure U-profile traverse, welded structure I-profile traverse, and assembled structure I-profile traverse are given.

As can be seen in Table 3, as a result of the transformation of the welded structure U-profile traverse to the assembled structure I-profile traverse, the deformation decreased by approximately $52 \%$ and the stresses increased by $18 \%$. It is evaluated within the framework of the safety factor that this increase in stress will not cause any problems in terms of safety.

Table 3: Stress and Deformation According to Travers Type

\begin{tabular}{|c|c|c|}
\hline Types of Traverse Structure & Stress & Deformation \\
\hline The Welded Structure U-profile Traverse & $355 \mathrm{MPa}$ & $19 \mathrm{~mm}$ \\
\hline Welded Structure I-profile Traverse & $404 \mathrm{MPa}$ & $20 \mathrm{~mm}$ \\
\hline The Assembled Structure I-profile Traverse & $420 \mathrm{MPa}$ & $10 \mathrm{~mm}$ \\
\hline
\end{tabular}

When the data obtained are evaluated in terms of production;

- It has been observed that the assembly time of the trailer chassis produced with the assembled I-profile traverse structure is $10 \%$ less than the assembly time of the chassis produced with the welded U-profile traverse structure.

- Due to the use of traditional production methods, it has been observed that the cost of the chassis produced with the assembled I-profile traverse structure is lower than the cost of the chassis produced with the welded U-profile traverse structure.

- While the chassis produced with welded U-profile traverse structure is a single piece, there is a problem in transportation, it has been observed that the chassis produced with the assembled I-profile traverse structure provides ease of transportation since it has three parts by demountability.

\section{CONCLUSION}

In this study, the welded U-profile traverse structure was transformed into an assembled I-profile traverse structure. As a result of the study, it was seen that the assembled structure has a $51 \%$ advantage over the welded structure in terms of deformation. However, it was observed that the assembled structure did not cause any problems in terms of safety in the stress data obtained. It is predicted that it will be widely used in the coming years due to its advantages such as short assembly time, low production cost, ease of transportation, and demountability.

\section{REFERENCES}

[1] Al., T.F.L. et., (1992). Member Stiffness and Bolt Spacing of Bolted Joints. Winter Annual Meeting of the American Society of Mechanical Engineers, Anaheim: Winter Annual Meeting of the American Society of Mechanical Engineers p. 63-72.

[2] Dundar, K., Ozkan, M.T., (2005). Civatalı Bağlantıların Eleman Direngenliğin Sonlu Elemanlar Yöntemi Ve Yapay Sinir Ağları Sistemi Ile Belirlenmesi. Teknoloji. 8(1): 33-41.

[3] Shigley, J.E., Mitchell, L.D., (1983). "Bolted Joint", Mechanical engineering design. Newyork: McGraw Hill Inc.

[4] Lehnhoff, T.F., Ko, K. II., McKay, M.L., (1994). Member Stiffness and Contact Pressure Distribution of Bolted Joints. Journal of Mechanical Design. 116(2): 550-7. doi: 10.1115/1.2919413.

[5] Wileman, J., Choudhury, M., Green, I., (1991). Computation of member stiffness in bolted connections. Journal of Mechanical Design, Transactions of the ASME. 113(4): 432-7. doi: 10.1115/1.2912801. 
[6] Akkurt, M., (1986). "Civata bağlantıları", Makina elemanları". Istanbul: Birsen Kitabevi.

[7] Filiz, I., H., Akbolat, A., Güzelbey, I.H., (1996). Stiffness of bolted members. Turkish Journal of Engineering and Environmental Sciences. 20: 273-9.

[8] Englund, R.B., Johnson, D.H., (1997). Finite element analysis of a threaded connection compared to experimental and theoretical research. Journal of Engineering Technology. 14(2): 42-7.

[9] Ibrahim, R.A., Pettit, C.L., (2005). Uncertainties and dynamic problems of bolted joints and other fasteners. Journal of Sound and $\mathrm{Vi}$ bration. 279(3-5): 857-936. doi: 10.1016/j.jsv.2003.11.064.

[10] Olsson, J., Sandlund, P., (2008). Form the Design Basis for Screw Joints. The Lulea University of Technology, (2008).

[11] Oldfield, M., Ouyang, H., Mottershead, J.E., (2005). Simplified models of bolted joints under harmonic loading. Computers and Structures. 84(1-2): 25-33. doi: 10.1016/j.compstruc.2005.09.007.

[12] Ouyang, H., Oldfield, M.J., Mottershead, J.E., (2006). Experimental and theoretical studies of a bolted joint excited by a torsional dynamic load. International Journal of Mechanical Sciences. 48(12): 1447-55. doi: 10.1016/j.ijmecsci.2006.07.015.

[13] Jiang, Y., Zhang, M., Lee, C.H., (2003). A study of early stage self-loosening of bolted joints. Journal of Mechanical Design, Transactions of the ASME. 125(3): 518-26. doi: 10.1115/1.1586936.

[14] Karim, Y., Blanzé, C., (2014). Vibration reduction of a structure by design and control of a bolted joint. Computers and Structures. 138: 73-85. doi: 10.1016/j.compstruc.2014.02.009.

[15] Liu, J., Ouyang, H., Feng, Z., Cai, Z., Mo, J., Peng, J., et al., (2019). Dynamic behaviour of a bolted joint subjected to torsional excitation. Tribology International. 140: 105877. doi: 10.1016/j.triboint.2019.105877.

[16] Gürsel, K.T., Yarkın, T., (2014). Otomobillerin Şasi Montajlarında Cıvata Sıkma Limitlerinin Saptanması. Journal of Polytechnic. 17(4): 193-202.

[17] Aslantas, K., I., U., Tasgetiren, S., (2004). Civata-Somun bağlantı sistemlerinde temas gerilmelerinin üç, boyutlu analizi. Makine Teknolojileri Elektronik Dergisi. (2): 50-5.

[18] Filiz, I., H., Kanber, B., (2007). Çoklu Civatalı Bağlantıların Kesme Ve Eğme Yükleri Alıında Incelenmesi. Çoklu Civatalı Bağlantıların Kesme Ve Eğme Yükleri Altında Incelenmesi, ISPARTA: XV. Ulusal Mekanik Kongresi,03-07 Eylül 2007.

[19] Bıyık, A., Baykasoglu, A., Erbil, E., Ince, U., (2016). Civatalı Bağlantıların Titreşim Altında Gevşemesinin Genetik Programlama Ve Regresyon Analizi Ile Tahmini. Bursa: 8. Otomotiv Teknolojileri Kongresi.

[20] Bhushan, V., Yadav, S.D., (2018). Design and analysis of 30 ton trailer chassis frame to reduce pollution by decreasing the emission through weight reduction using advanced lightweight material. International Journal of Mechanical Engineering and Technology. 9(6): 705-22.

[21] Tello, L., Castejon, L., Malon, H., Valladares, D., Luque, P., Mantaras, D.A., et al., (2020). Development of a fatigue life prediction methodology for welded steel semi-trailer components based on a new criterion. Engineering Failure Analysis. 108: 104268. doi: 10.1016/j. engfailanal.2019.104268. 